\title{
MOBILITY AND STAGNATION IN INDIA'S RURAL LABOUR MARKET
}

Rajarshi Majumder*

\begin{abstract}
Transformation of the countryside from agrarian subsistence economy to nonfarm monetised economy is propagated as a precursor of growth and development that involves shifting of labour from farming to off-farm activities. India has started its journey in this path but has a long way to go. Researchers also question the changing pattern of rural labour movement as a positive phenomenon or a distress one. This paper attempts to examine the complexity of changes in rural labour market in India over a quarter of a century to untangle the dynamics. It is observed that the changes taking place are not always conducive to progress as a large part of it is distress-driven. While some social groups are going up the ladder, a large mass of others are stagnating in the same or similar occupations. It appears that agriculture still holds the key to rural development. A three-pronged strategy of agricultural progress, human capital formation and rural industrialisation is necessary for breaking the shackles of continuity and usher in changes that are real rather than apparent.
\end{abstract}

\section{Introduction}

Development theories lay great emphasis on the necessity of transforming a predominantly agrarian subsistence economy to a non-farm monetised economy as a facilitator of growth and development. The process involved in such a transformation includes movement of workers from agriculture to secondary and tertiary sectors, from cultivation to non-farm activities, from self-employment to wage labour - both over time and across generations. India has started its journey on this path but has a long way to go yet as close to two-third of its population and workforce are still dependent on agriculture for their livelihood. In addition, this linear model of development has been questioned recently; researchers commenting that the transformation process in the labour profile may be forced and distress-driven rather than dynamic and due to pull factors (a forceful argument by Abraham, 2009 and also by Sen $\&$ Jatav, 2010). This paper explores these issues related to the changing pattern of rural labour

*Professor, Department of Economics, University of Burdwan, West Bengal, email: meriju@rediffmail.com. 
market in India over a quarter of a century using large sample survey data from National Sample Survey Office ${ }^{1}$ (NSSO) of India. We observe that the changes occurring in the countryside carry both signs of change and continuity. A section of the population, mostly from the advanced social classes, has experienced sectoral mobility and vertical movements. But for a large section, especially the Scheduled Caste (SC) population, the movements are lateral from one low-paying job to another, and mostly driven out of despair. The changing occupational distribution is, therefore, to a large extent apparent and in reality there are clear symptoms of stagnation, which, if overlooked, has serious implications for the development process in general and social inclusion in particular.

\section{Current Research Base}

India's rural economy, especially the agricultural sector has seen a lively and rich research body developing around it, befitting its central role in the social, economic, and political processes. Most of these have dwelt on the situation of rural labour,either briefly or at length [see Bardhan (1977) for a survey of research till late 1970s and Coppard (2001) for an excellent survey of more recent literature focussed on rural non-farm sector].Apart from those already mentioned, studies that focus specifically on rural labour include Sastry (2002), Bhaumik (2002), Chadha\&Sahoo (2002), Bhalla (2003), Deshingkar and Farrington (2006), Eswaran et al (2009), Ranjan (2009), Binswanger-Mkhize (2013). Almost all these studies report a declining share of agriculture and farming among rural workers and movement onto secondary and tertiary sectors. However, the dynamics and the merit of such changes have been questioned in recent years and the jury is divided on whether the changes are growth-driven and virtuous or distressdriven and vicious. We critically analyse the changes observed over a long time period of a quarter of a century to smooth over periodical short-term disturbances by looking at parametres like employment status, sectoral and occupational distributions, wage and consumption levels and movements over time and generations. 
Figure 1: Rural Transformation - A Framework

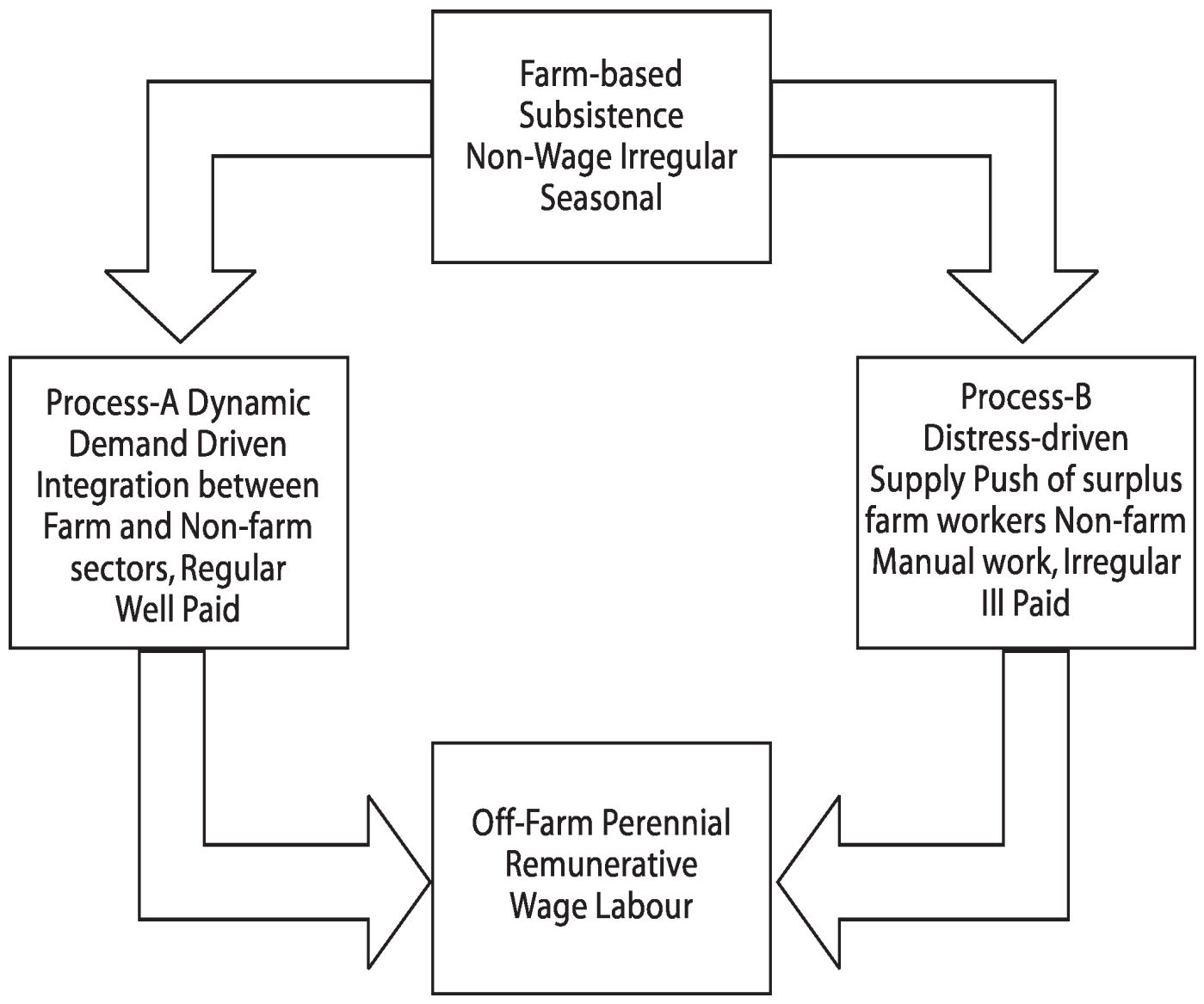

There is no doubting the fact that structural transformation of rural India would necessitate shift from farm-based, subsistence, non-wage, and irregular work to off-farm remunerative wage labour over time (Figure 1). However, there may be two completely different processes that may lead to such an outcome. In one, there is a dynamic integration of farm and non-farm sectors leading to demand-driven shift of workers from agriculture and cultivation to manufacturing and services.The resultant jobs are regular and well-paid, leading to improvement in livelihood and economic status. The other process is a distress-driven supply push of surplus farm workers into non-farm manual jobs that are irregular and ill-paid, leading to further immiseration. Which of these two processes is actually operating would be evident by examining the indicators that are associated with these processes (Figure 2). The results discussed below would provide us a clue to the process. 
Figure 2: Processes and Indicators

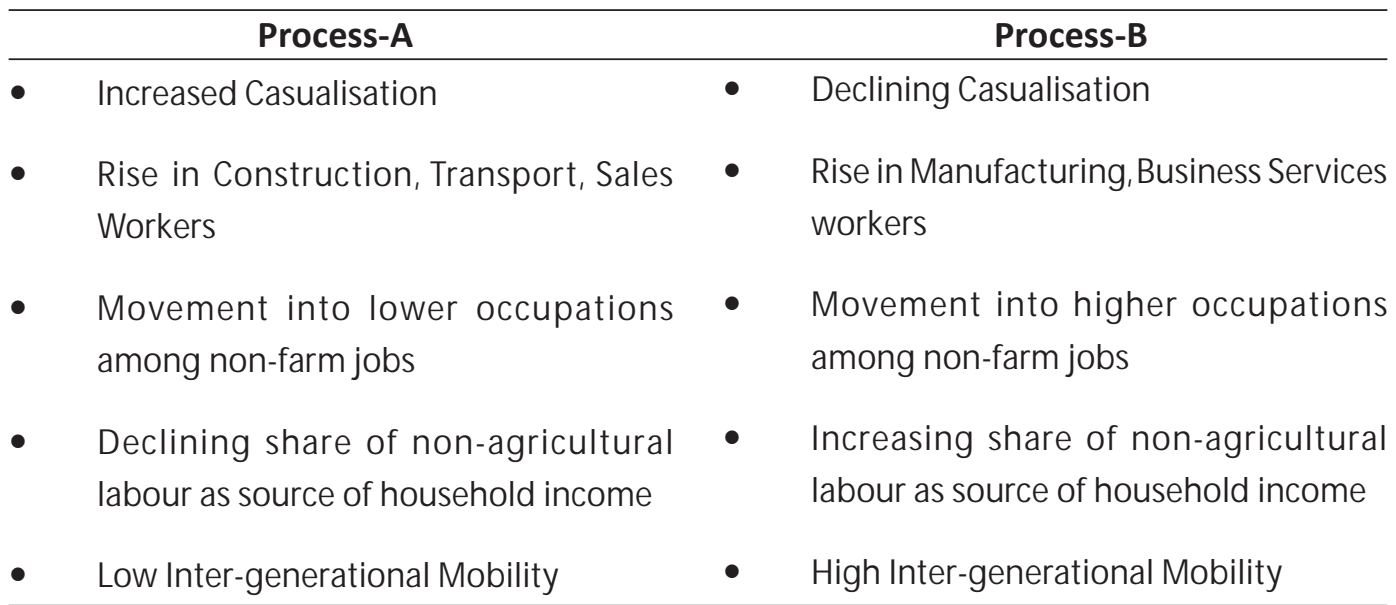

\section{Results and Discussion}

Employment Status: The quarter century period of 1983-2009 has witnessed a marginal drop in Labour Force Participation Rate (LFPR) in rural India at the aggregate (Tables $1 \& 2$; Figure 3). This has been accompanied by a fall in employment rate as well, indicating lower absorption of rural labour into productive jobs. Self-employment, especially in agriculture,has declined along with a rise in casual wage labour. Regular salaried work has increased in Punjab, Haryana, Gujarat, Tamil Nadu and Himachal Pradesh, but has declined elsewhere, indicating its link with the economically betteroff States. Thus the broad picture is that of increased work participation, declining labour absorption, and increased casualisation.

Table 1: Rural Work Participation and Employment Types

\begin{tabular}{lcccccc}
\hline \multirow{2}{*}{\multicolumn{1}{c}{ Category }} & \multicolumn{3}{c}{1983} & \multicolumn{5}{c}{2009} \\
\cline { 2 - 7 } & Male & Female & All & Male & Female & All \\
\hline Not in labour force $^{\circledR}$ & 45.5 & 58.5 & 51.8 & 45.0 & 61.3 & 53.0 \\
Unemployed\# & 2.1 & 1.4 & 1.9 & 1.9 & 2.4 & 2.1 \\
Self-employed $^{\wedge}$ & 59.5 & 54.1 & 57.8 & 53.0 & 50.3 & 52.3 \\
Casual labourer $^{\wedge}$ & 29.8 & 42.2 & 33.7 & 38.3 & 44.2 & 39.9 \\
Regular salaried worker $^{\wedge}$ & 10.1 & 3.6 & 8.1 & 8.7 & 5.5 & 7.8 \\
\hline
\end{tabular}

Source: Author's calculation based on NSSO $(1983,2010)$.

Note: @ - as percentage of $6+$ population; \#- as percentage of labour force; ^ - as percentage of total workers

Journal of Rural Development, Vol. 36, No. 1, January - March : 2017 


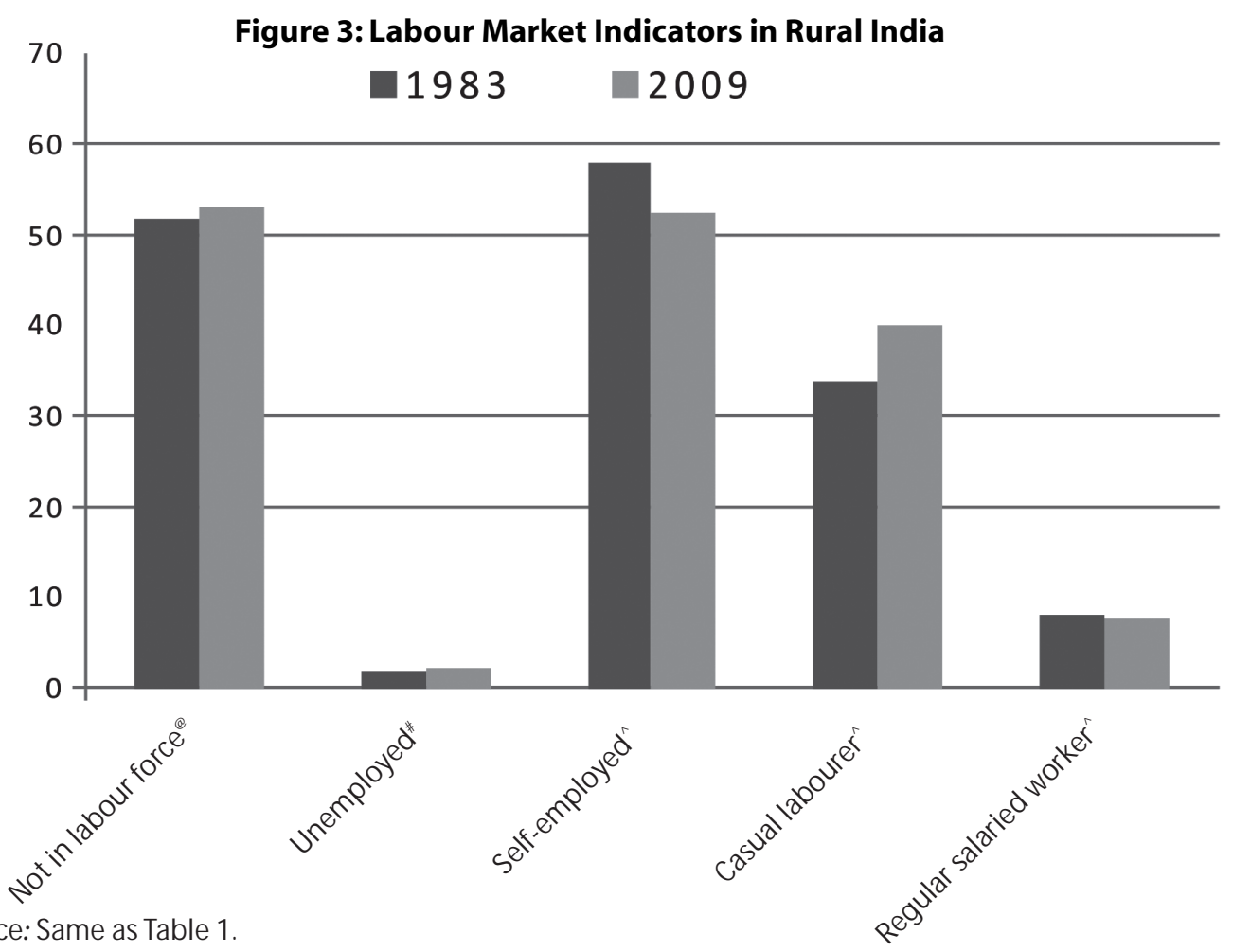

Table 2: Growth in Rural Work Participation and Employment Types - 1983-2009

\begin{tabular}{lccc}
\hline \multicolumn{1}{c}{ Category } & Male & Female & All \\
\hline Not in labour force & 1.6 & 1.8 & 1.7 \\
Unemployed & 1.2 & 3.9 & 1.8 \\
Self-employed & 1.2 & 0.3 & 0.9 \\
Casual labourer & 3.4 & 0.8 & 2.4 \\
Regular salaried worker & 1.0 & 2.9 & 1.2 \\
\hline
\end{tabular}

Source: Author's calculation based on NSSO $(1983,2010)$.

Social stratification prevents this broad trend to be applicable across the spectrum. There has been absolute decline in the number of Hindu Upper Caste (HUC) workers all along - mirroring the substantial rural-urban migration observed among this social class facilitated by their superior social, economic and human capital profile. Casualisation has also declined for this group and includes just about one-fourth of all HUC workers. On the contrary, incidence of casual wage labour is above 40 per cent for Hindu Scheduled Tribe (HST) workers and over 60 per cent for Hindu Scheduled Caste (HSC) workers, and has been increasing over this period. Thus, the processes of change in employment status are different 
across socio-religious groups with the HUCS clearly having an edge over the others.

Sectoral \& Occupational Changes: There is no doubt that over this quarter century workers in rural India have moved out of agriculture, now accounting for two-thirds of all rural workers compared to more than four-fifths in 1983 (Tables $3 \& 4$, Figure 4). Sectors that have gained from this outflow are construction $(+6.5$ percentage points), trade, hotel, $\&$ restaurant
$(+4.0)$, manufacturing $(+3.0)$ and transport \& communication ( +2.5$)$. This has been paralleled by changes in occupational divisions also (Tables $5 \& 6$, Figure 5). While farming as an occupation declined in importance, major gainers have been production $\&$ construction related jobs (+13 percentage points), administrative \& managerial jobs $(+2.5)$, and technical and professional jobs (+2.2).

Table 3: Rural Employment by Major NIC Sectors

\begin{tabular}{|c|c|c|c|c|c|c|}
\hline \multirow{2}{*}{ Category } & \multicolumn{3}{|c|}{1983} & \multicolumn{3}{|c|}{2009} \\
\hline & Male & Female & All & Male & Female & All \\
\hline $\begin{array}{l}\text { Agriculture, including } \\
\text { forestry \& fishing }\end{array}$ & 82.6 & 88.2 & 85.2 & 62.5 & 78.9 & 66.8 \\
\hline Mining & 0.1 & 0.1 & 0.1 & 0.8 & 0.3 & 0.7 \\
\hline Construction & 4.0 & 2.8 & 3.1 & 11.4 & 4.2 & 9.5 \\
\hline Manufacturing & 4.4 & 4.1 & 4.2 & 7.1 & 7.6 & 7.2 \\
\hline Elec, gas \& water & na & $\mathrm{Na}$ & na & 0.2 & na & 0.2 \\
\hline Transport, St \& omm & 0.7 & 0.1 & 0.6 & 4.2 & 0.3 & 3.2 \\
\hline Fin $\&$ business services & 0.1 & $\mathrm{Na}$ & 0.1 & 0.8 & 0.2 & 0.6 \\
\hline Trade, hotel \& restaurants & 4.1 & 0.5 & 2.8 & 8.2 & 3.1 & 6.8 \\
\hline $\begin{array}{l}\text { Community, social \& } \\
\text { personal services }\end{array}$ & 3.9 & 4.3 & 4.0 & 4.6 & 4.8 & 4.6 \\
\hline
\end{tabular}

Source: Author's calculation based on NSSO $(1983,2010)$.

Note:Columns do not add up to 100 due to rounding off and leaving out of minor sectors; na - denotes negligible share. 
Mobility and Stagnation in India's Rural Labour Market

Table 4: Growth in Rural Employment by Major NIC Sectors - 1983-2009

\begin{tabular}{lccl}
\hline \multicolumn{1}{c}{ Category } & Male & Female & All \\
\hline Agricultural & -0.2 & -0.3 & -0.2 \\
Mining & 46.5 & 15.5 & 38.7 \\
Construction & 60.2 & 20.3 & 49.8 \\
Manufacturing & 24.3 & 27.3 & 25.1 \\
Elec, gas \& water & 44.2 & 15.5 & 39.7 \\
Transport, St \& Comm & 68.3 & 68.5 & 68.3 \\
Fin \& business services & 75.4 & 103.5 & 77.0 \\
Trade, hotel \& restaurants & 32.4 & 16.5 & 29.6 \\
Community, social \& personal services & 26.2 & 62.4 & 31.4 \\
\hline
\end{tabular}

Source: Author's calculation based on NSSO $(1983,2010)$.

Figure 4: Rural Employment by NIC Groups in India

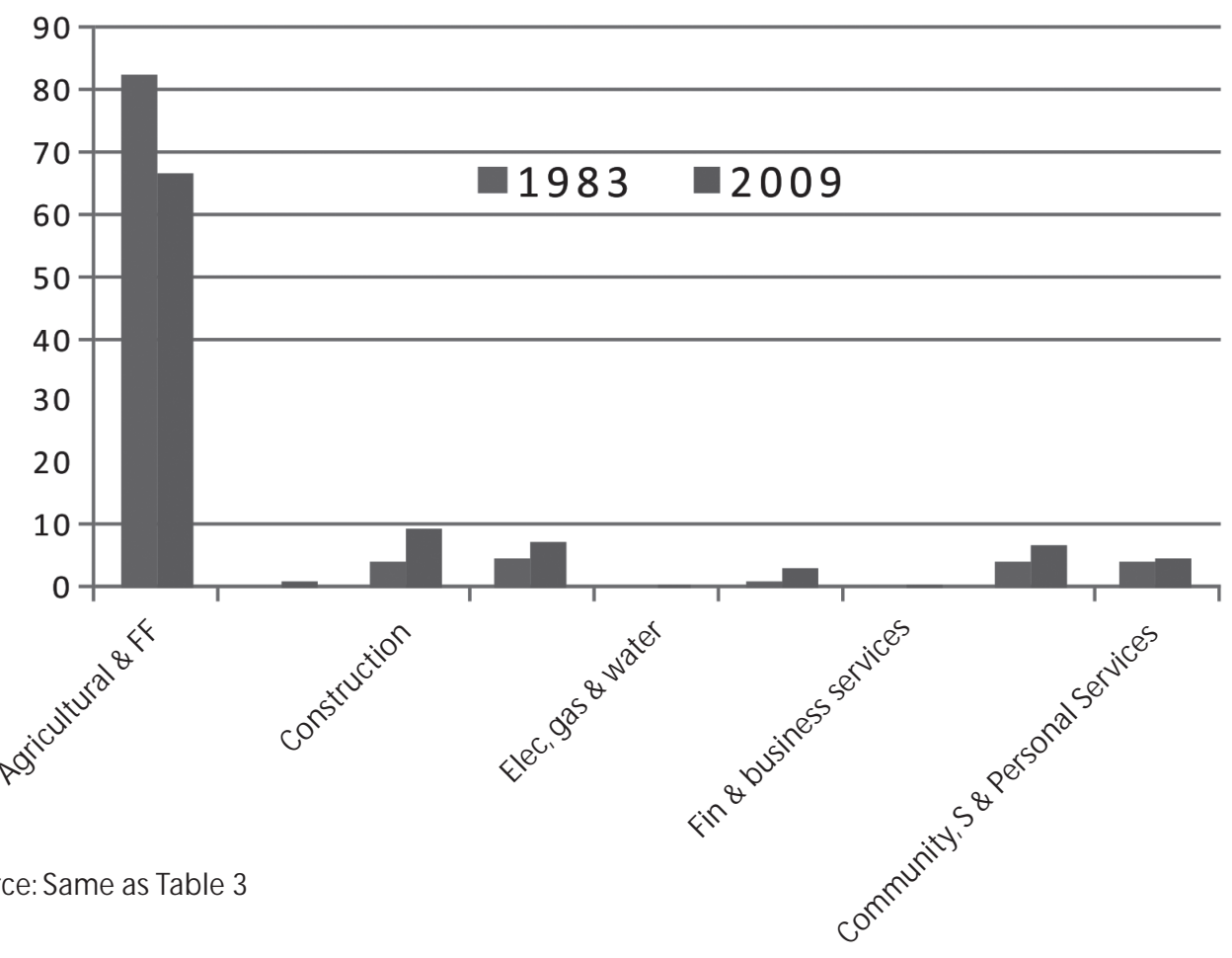

Journal of Rural Development, Vol.36, No. 1, January - March : 2017 
Again, these shifts are not uniform across social groups.The HSTs have seen lowest decline in share of agriculture/farming, indicating their continued dependence on land/forests for livelihood. Highest decline in share of land based activities has been for the HSCs, most of who have moved into the construction sector, reflecting perhaps the landlessness and increasing land alienation within this group. For the HUCs, the movement is mainly from agriculture to manufacturing and trade at the sectoral level and from farming to administrative, managerial, sales, and professional jobs at the occupational level.

Table 5: Rural Employment by Major Occupation Groups

\begin{tabular}{lcccccc}
\hline \multirow{2}{*}{ Category } & \multicolumn{3}{c}{1983} & \multicolumn{3}{c}{2009} \\
\cline { 2 - 6 } & Male & Female & All & Male & Female & All \\
\hline Admin \& Managerial & 0.4 & 0.1 & 0.3 & 3.4 & 1.9 & 3.0 \\
Technical \& Professional & 1.4 & 0.3 & 1.1 & 3.5 & 3.1 & 3.4 \\
Clerical & 0.3 & 0.0 & 0.2 & 0.9 & 0.3 & 0.7 \\
Sales & 3.8 & 2.1 & 3.3 & 3.7 & 1.3 & 3.1 \\
Service & 1.0 & 0.8 & 0.9 & 1.8 & 1.2 & 1.6 \\
Farming & 83.2 & 90.0 & 85.3 & 62.7 & 78.8 & 67.0 \\
Production & 6.8 & 4.9 & 6.2 & 21.9 & 13.0 & 19.5 \\
Transport & 0.7 & 0.0 & 0.5 & 1.6 & 0.2 & 1.2 \\
\hline
\end{tabular}

Source: Author's calculation based on NSSO $(1983,2010)$.

Note:Columns do not add up to 100 due to rounding off.

Table 6: Growth in Rural Employment by Major Occupation Groups - 1983-2009

\begin{tabular}{lccc}
\hline \multicolumn{1}{c}{ Category } & Male & Female & All \\
\hline Admin \& Managerial & 178.2 & 261.1 & 188.4 \\
Technical \& Professional & 43.2 & 153.6 & 52.8 \\
Clerical & 50.9 & 233.4 & 55.6 \\
Sales & 14.2 & 5.7 & 12.6 \\
Service & 30.8 & 18.7 & 27.6 \\
Farming & 10.3 & 9.6 & 10.1 \\
Production & 56.4 & 37.0 & 51.8 \\
Transport & 38.3 & $\mathrm{Na}$ & 40.1 \\
\hline
\end{tabular}

Source: Author's calculation based on NSSO $(1983,2010)$.

Journal of Rural Development, Vol. 36, No. 1, January - March : 2017 
Figure 5: Rural Employment by Occupation Groups in India

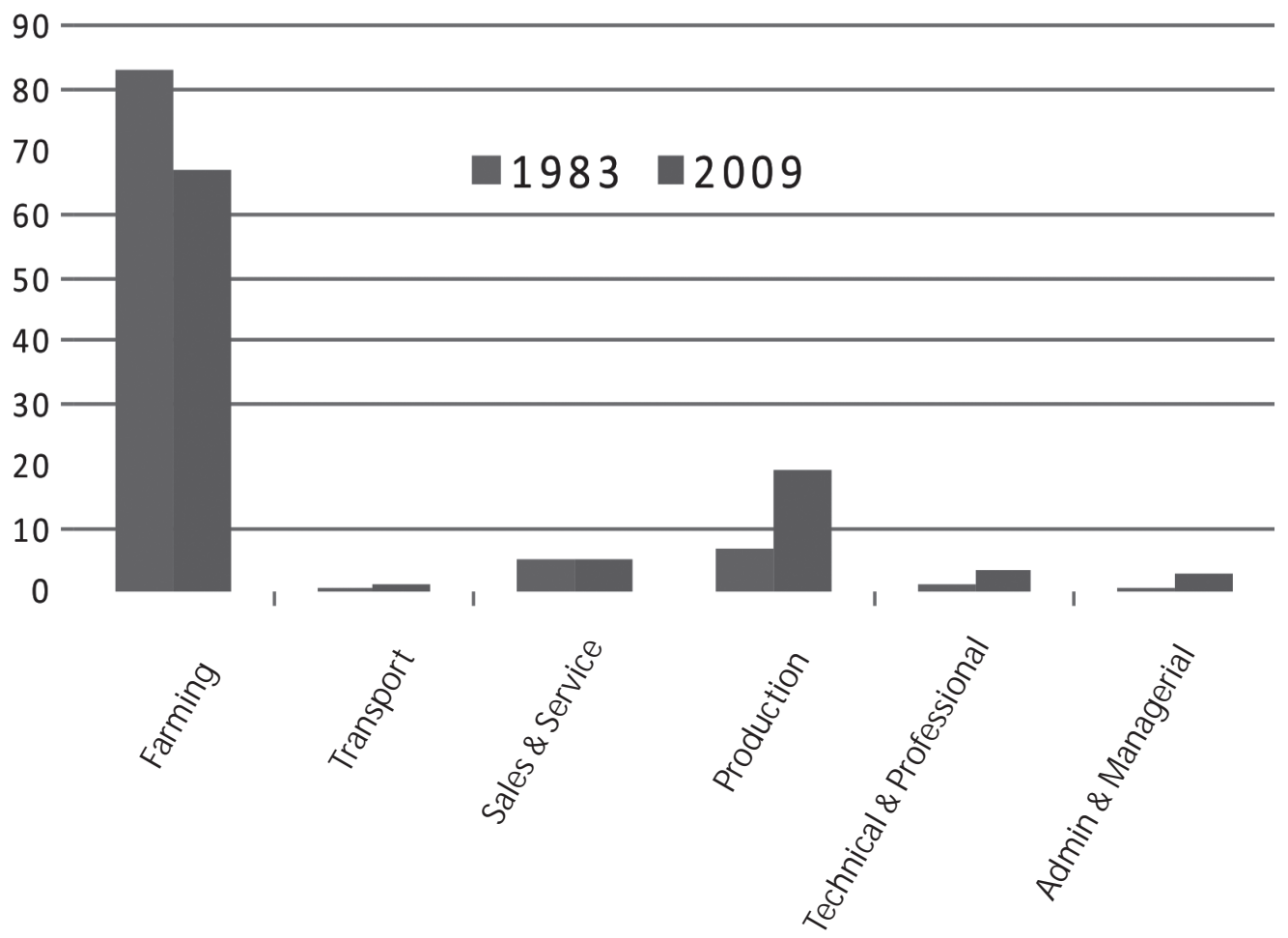

Thus we observe continuity for the HSTs in primary \& land-based activities, movement of HSCs into the lower rungs of secondary sector and climbing up towards better-off tertiary sector jobs by the HUCs.

Inter-generational Mobility: Are these movements breaking the shackles of traditional family occupation domain where children continue their parental jobs? This may be answered if we look at industrial/ occupational distribution of children (a mere euphemism for all 20+ population either of whose parents are still working) vis-a-vis their parents. It is observed that even among cohabiting households occupational and industrial pattern shows a shift from agriculture to construction, trade, manufacturing, and transport sectors over generations (Table 7). However, there is substantial stickiness as well as more than 75 per cent of agricultural sector workers have their children in this sector itself (Table 8). Similarly, 70 per cent of manufacturing \& construction sector workers have their children following in their footsteps. Inter-generational mobility is relatively higher among transport and community, social \& personal services sector workers where more 
than half of the children venture into sectors other than that of their parents. It is also noteworthy that there exist movements from non-agriculture sectors to agriculture sector over generations, though the magnitude is small.

Table 7: Changing Employment Structure across Generations

\begin{tabular}{lcclcc}
\hline \multicolumn{1}{c}{ NIC Category } & $\begin{array}{c}\text { Current } \\
\text { Generation }\end{array}$ & $\begin{array}{c}\text { Previous } \\
\text { Generation }\end{array}$ & Occupation Category & $\begin{array}{c}\text { Current } \\
\text { Generation }\end{array}$ & $\begin{array}{c}\text { Previous } \\
\text { Generation }\end{array}$ \\
\hline Agriculture & 67.6 & 73.0 & Admin \& Mang & 3.2 & 3.6 \\
Mining & 0.7 & 0.7 & Tech \& Prof & 1.8 & 1.3 \\
Construction & 9.4 & 7.2 & Clerical & 0.8 & 1.1 \\
Manufacturing & 7.0 & 4.8 & Sales & 3.2 & 3.6 \\
Elec, Gas \& Water & 0.2 & 0.2 & Service & 1.6 & 1.6 \\
Transport, St \& Comm & 3.2 & 2.2 & Farming & 41.4 & 54.8 \\
Fin \& business services & 0.7 & 0.5 & Production & 44.4 & 31.5 \\
Trade, hotel \& & & & & & \\
restaurants & 6.9 & 7.5 & Transport & 1.7 & 0.7 \\
CS\&P Services & 4.8 & 4.7 & & & \\
\hline
\end{tabular}

Source: Author's calculation based on NSSO (2010).

Note: Columns do not add up to 100 due to rounding off and leaving out of minor sectors.

Table 8: Movement Across Major NIC Groups Over Generations - Outflow Matrix

\begin{tabular}{lcccccc}
\hline \multicolumn{1}{c}{ NIC Category } & $\begin{array}{c}\text { Agricul- } \\
\text { ture }\end{array}$ & $\begin{array}{c}\text { Manufac- } \\
\text { turing }\end{array}$ & $\begin{array}{c}\text { Constr- } \\
\text { uction }\end{array}$ & $\begin{array}{c}\text { Trade \& } \\
\text { Hotels }\end{array}$ & $\begin{array}{c}\text { Transport, } \\
\text { St \& Comm }\end{array}$ & $\begin{array}{c}\text { CS\&P } \\
\text { Services }\end{array}$ \\
\hline Agriculture & 80.8 & 8.5 & 11.3 & 16.4 & 17.9 & 27.2 \\
Manufacturing & 4.4 & 70.3 & 8.3 & 7.5 & 12.2 & 5.9 \\
Construction & 6.0 & 6.0 & 69.0 & 8.5 & 13.0 & 8.5 \\
Trade, hotel \& restaurants & 3.2 & 6.6 & 4.3 & 58.0 & 5.6 & 15.1 \\
Transport, St \& Comm & 2.6 & 3.7 & 4.2 & 6.3 & 46.3 & 5.6 \\
CS \& P services & 3.2 & 4.8 & 2.9 & 3.3 & 4.9 & 37.7 \\
& 100.0 & 100.0 & 100.0 & 100.0 & 100.0 & 100.0 \\
\hline
\end{tabular}

Source: Author's calculation based on NSSO (2010).

At occupational level too, stickiness is high for farming and production and construction related jobs (Table 9). Movements from these occupations to administrative and managerial jobs are negligible. Again, there exist some workers who have moved into farming though their parents were in non-farm occupations. 
Mobility and Stagnation in India's Rural Labour Market

Table 9: Movement Across Major Occupation Groups Over Generations - Outflow Matrix

\begin{tabular}{lcccc}
\hline \multicolumn{1}{c}{ Occupation Category } & Farming & Production & $\begin{array}{c}\text { Admin } \\
\text { \&Mang }\end{array}$ & Others \\
\hline Farming & 72.7 & 5.0 & 12.1 & 19.2 \\
Production & 16.8 & 85.8 & 16.5 & 24.0 \\
Admin \& managerial & 3.4 & 2.2 & 56.4 & 5.8 \\
Others & 7.1 & 7.0 & 15.0 & 51.0 \\
& 100.0 & 100.0 & 100.0 & 100.0 \\
\hline
\end{tabular}

Source: Author's calculation based on NSSO (2010).

The fluidity observed earlier over time is, therefore, working within households as well where current generation workers are moving out of parental industry/occupation. But we now have evidence that the shift is not always a one way traffic out from primary sector/ occupations. People,though small in numbers, are moving into land based activities as well and the transformation process is stymied rather than full-fledged.

\section{Mobility and Stagnation}

While the evidence so far suggests considerable mobility in the rural labour scenario, we have also observed signs of stagnation across generations and for some social groups. This will become clearer if we cross-tabulate industrial sectors and occupations (Table 10).

Table 10: Employment Share by Industry and Occupation

\begin{tabular}{lcccc}
\hline \multicolumn{1}{c}{ NIC Category } & 1983 & 2009 & $\begin{array}{c}\text { Previous } \\
\text { Generation }\end{array}$ & $\begin{array}{c}\text { Current } \\
\text { Generation }\end{array}$ \\
\hline Agriculture & 85.2 & 66.6 & 71.6 & 65.8 \\
Farming & 85.1 & 66.0 & 53.9 & 39.2 \\
Food Processing & 0.1 & 0.6 & 17.7 & 26.6 \\
Manufacturing & 4.1 & 6.7 & 4.4 & 6.7 \\
Labourers & 0.2 & 1.0 & 0.1 & 0.1 \\
Artisans & 3.8 & 5.1 & 3.9 & 6.0 \\
Admin & 0.1 & 0.6 & 0.4 & 0.6 \\
Construction & 3.1 & 8.9 & 6.3 & 8.7 \\
Labourers & 3.0 & 8.8 & 6.2 & 8.6 \\
Admin & 0.1 & 0.1 & 0.1 & 0.1 \\
\hline
\end{tabular}

Journal of Rural Development, Vol. 36, No. 1, January - March :2017 
Table 10: Contd.....

\begin{tabular}{lcccc}
\hline NIC Category & 1983 & 2009 & $\begin{array}{c}\text { Previous } \\
\text { Generation }\end{array}$ & $\begin{array}{c}\text { Current } \\
\text { Generation }\end{array}$ \\
\hline Trade \& hotels & 2.8 & 5.3 & 6.0 & 5.6 \\
Workers & 2.7 & 3.9 & 4.3 & 4.1 \\
Admin & 0.1 & 1.4 & 1.7 & 1.5 \\
Transport, St \& comm & 0.6 & 2.6 & 1.6 & 2.8 \\
Producers & 0.1 & 1.7 & 1.0 & 1.6 \\
Operators & 0.5 & 0.9 & 0.6 & 1.2 \\
Services & 4.1 & 4.4 & 4.3 & 4.5 \\
Operators & 1.8 & 3.8 & 3.4 & 3.9 \\
Admin & 0.1 & 0.6 & 0.9 & 0.6 \\
Others & 2.2 & 5.3 & 5.7 & 5.9 \\
\hline
\end{tabular}

Source: Author's calculation based on NSSO $(1983,2010)$.

It is observed that while workers in agriculture sector have declined as a whole, there has been a rise in processing jobs within agro-sector indicating saturation or even overflow, of farming/cultivation in terms of labour absorption. Increasing share of manufacturing sector workers has been mainly in the form of increased labourers compared to artisans and self-employed.Almost all of the increase in construction and service sector jobs has been for labourers and service providers rather than in administrative/managerial jobs. For trade and hotels etc., sector too, the increase has been mainly in the form of sales workers and servicemen and not for managerial jobs. Only for the transport sector we observe a balanced rise in transport equipment producers and transport operators.
It is, therefore, evident that the movement of workers away from the agriculture sector involves mainly a shift of surplus farm-labour into other non-farm manual work, especially in construction, manufacturing and transport. If this shift is demand-induced and growth-driven, then it would be dynamic and is likely to lead to a virtuous development trajectory. However, if the shift is supply-induced and distress-driven, then the process is likely to create stagnation and crisis in the countryside.

We can get some idea about the process if we look at the sources of income and consumption pattern. The myth that shift of workers from agro-labour to non-agro labour is always beneficial is perpetuated by the fact that households whose predominant source of 
income is non-agro labour have an average consumption level that is more than twice of the households whose predominant source is agro-labour (Table 11, Figure 6). There are also evidences to show that productivity, wages and working conditions are generally higher in the non-farm sector than in the farm sector (Fisher and Mahajan, 1998). In addition, Monthly Percapita Consumption Expenditure (MPCE) of non-agro-labourhouseholds have increased by close to 7 per cent per annum over this quarter century while that of agro-labour households have marginally declined (Table 12).

Table 11: MPCE by Predominant Source of Income and Socio-religious Group

\begin{tabular}{lccccccccc}
\hline \multicolumn{1}{c}{ Social Group } & \multicolumn{4}{c}{1983} & \multicolumn{5}{c}{2009} \\
\hline Hindu Upper & SEAg & AgLab & NAgLab & SENAg & SEAg & AgLab & NAgLab & SENAg \\
Hindu OBC & 905 & 766 & 644 & 882 & 1074 & 869 & 2318 & 1185 \\
Hindu SC & na & na & na & Na & 959 & 802 & 1504 & 986 \\
Hindu ST & 870 & 696 & 563 & 621 & 805 & 748 & 1085 & 885 \\
Muslims & 632 & 667 & 568 & 1404 & 739 & 651 & 1100 & 796 \\
\hline All Total & 887 & 1009 & 615 & 673 & 873 & 725 & 1236 & 957 \\
\hline
\end{tabular}

Source: Author's calculation based on NSSO $(1983,2010)$.

Note: MPCE are at constant 2009-10 prices, deflated using CPIAL linked series.

Figure 6: MPCE in Rural India by Social Group and Predominant Source of Household Income (₹ per month at constant 2009-10 prices)

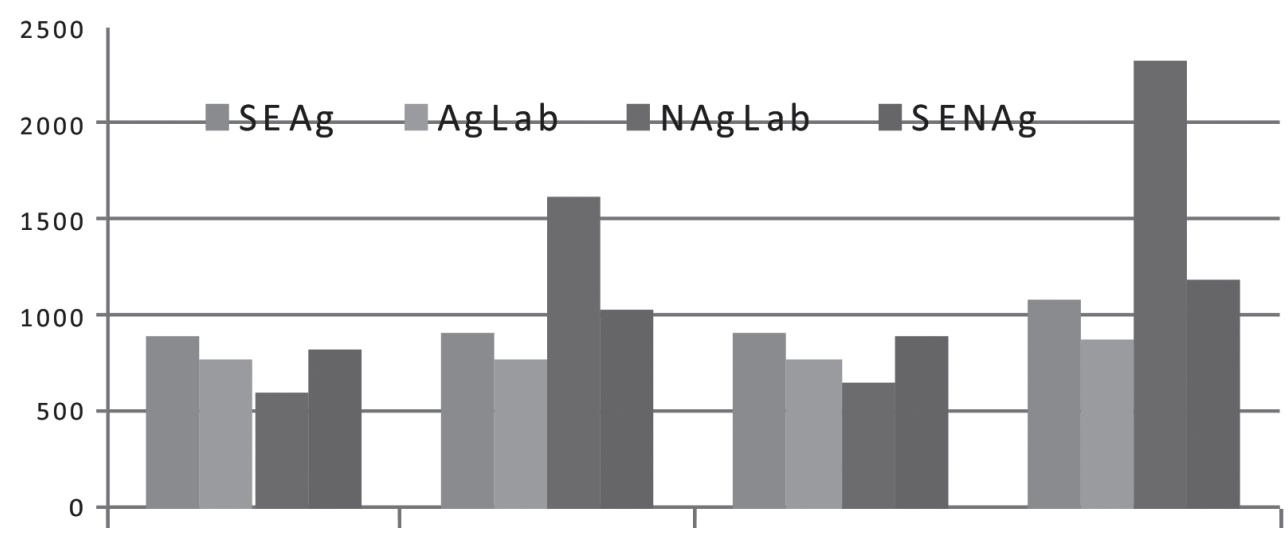

Source:Author's calculation based on NSSO $(1983,2010)$.

Journal of Rural Development, Vol. 36, No. 1, January - March :2017 
Table 12: Growth in MPCE by Predominant Source of Income and Socio-religious Group

\begin{tabular}{lcccc}
\hline \multicolumn{1}{c}{ Social Group } & \multicolumn{5}{c}{$1983-2009$ (\% pa) } \\
\hline Hindu Upper & SEAg & AgLab & NAgLab & SENAg \\
Hindu SC & 0.75 & 0.54 & 10.40 & 1.37 \\
Hindu ST & -0.30 & 0.30 & 3.71 & 1.70 \\
Muslims & 0.68 & -0.10 & 3.75 & -1.73 \\
& -0.06 & -1.13 & 4.04 & 1.69 \\
\hline All Total & 0.06 & -0.01 & 6.69 & 0.96 \\
\hline
\end{tabular}

Source: Author's calculation based on NSSO $(1983,2010)$.

However, this does not guarantee that workers moving into non-agro sectors will be assured of such higher levels of wage, income and consumption. What has been the data and evidence in this regard? We observe that proportion of households who report that cultivation is their predominant source of income have dropped from 41 to 32 per cent over the quarter century, which is expected in the light of employment dynamics observed earlier (Table 13, Figure 7).

Table 13: Households by Predominant Source of Income and Socio-religious Group

\begin{tabular}{lcccccccc}
\hline \multicolumn{1}{c}{ Social Group } & \multicolumn{4}{c}{1983} & \multicolumn{5}{c}{2009} \\
\hline Hindu Upper & SEAg & AgLab & NAgLab & SENAg & SEAg & AgLab & NAgLab & SENAg \\
Hindu OBC & 48.6 & 5.6 & 22.2 & 12.2 & 44.3 & 8.0 & 13.7 & 16.1 \\
Hindu SC & na & na & na & Na & 36.2 & 13.2 & 23.6 & 16.2 \\
Hindu ST & 20.4 & 8.3 & 54.0 & 10.1 & 17.7 & 22.2 & 36.3 & 13.9 \\
Muslims & 43.4 & 7.1 & 38.9 & 4.7 & 35.4 & 13.8 & 35.7 & 6.3 \\
& 33.3 & 8.1 & 28.1 & 19.8 & 21.4 & 17.5 & 23.2 & 24.9 \\
\hline All Total & & & & & & & & \\
\hline
\end{tabular}

Source: Author's calculation based on NSSO $(1983,2010)$. 
Figure 7: Predominant Source of Income of Households in Rural India

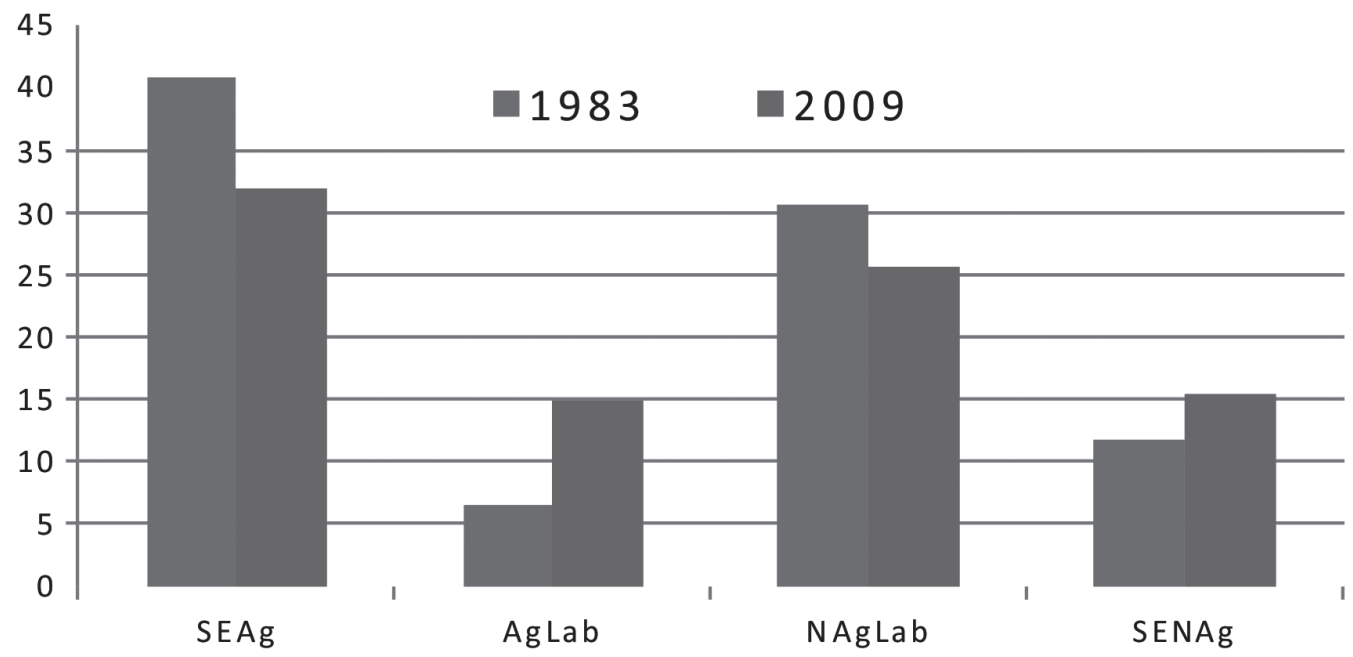

Source: Same as Table 13.

Also expected is the increased share of households who report self-employment in non-agriculture as their predominant source of income because of the rise in share of technical and professional occupation and trade and hotel sector jobs. However, bewildering is the fact that households reporting agricultural labour as their predominant source of income have gone up while those reporting nonagricultural labour have gone down. Thus we have a seemingly paradoxical situation where share of wage labourers in non-agro sectors is going up but proportion of households reporting these jobs as their major income source is declining. This is only possible if majority of the non-agricultural wage labourers are engaged in low paying irregular jobs, and households have a diversified labour-use pattern with some family members (who are surplus farm labour) taking up whatever off- farm work is available to supplement family income.This is supported by the fact that wage increase over these 25 years has been lowest in construction sector, followed by production, sales and transport - specifically the very sectors which have witnessed inflow of workers in recent times (Tables $14 \& 15$, Figure 8). The process at play is thus a distress-driven supply push of surplus agricultural labourers into nonfarm jobs that are irregular and ill-paid and do not contribute much to the gross household income. Added to this is the fact that while share of non-agro-labour households are going down, their average consumption level is going up.This is clearly leading to increased inequality in the countryside with pauperisation of the masses and increased riches for a select few. Social inequality is also increasing as the processes are different across social groups as mentioned earlier. 
Table 14: Real Wage by Occupation and Socio-religious Group (₹ per week)

\begin{tabular}{lcccccccc}
\hline \multicolumn{1}{c}{ Sector / Occupation } & \multicolumn{4}{c}{1983} & \multicolumn{5}{c}{2009} \\
\hline Farming & HST & HSC & HUC & MUS & HST & HSC & HUC & MUS \\
Transport & 128 & 157 & 255 & 145 & 376 & 411 & 478 & 489 \\
Sales & 145 & 174 & 278 & 162 & 546 & 698 & 779 & 800 \\
Production & 174 & 180 & 186 & 232 & 631 & 637 & 693 & 769 \\
Construction & 168 & 244 & 238 & 215 & 607 & 686 & 967 & 755 \\
Tech \& Prof & 174 & 209 & 267 & 128 & 519 & 618 & 783 & 674 \\
Admin \& Man & 354 & 139 & 568 & 273 & 2031 & 2185 & 2658 & 2064 \\
\hline
\end{tabular}

Source: Author's calculation based on NSSO $(1983,2010)$.

Note: Wages are at constant 2009-10 prices, deflated using CPIAL linked series.

Figure 8: Real Wage Rates in Rural India by Occupation ( $₹$ per week at constant 2009-10 prices)

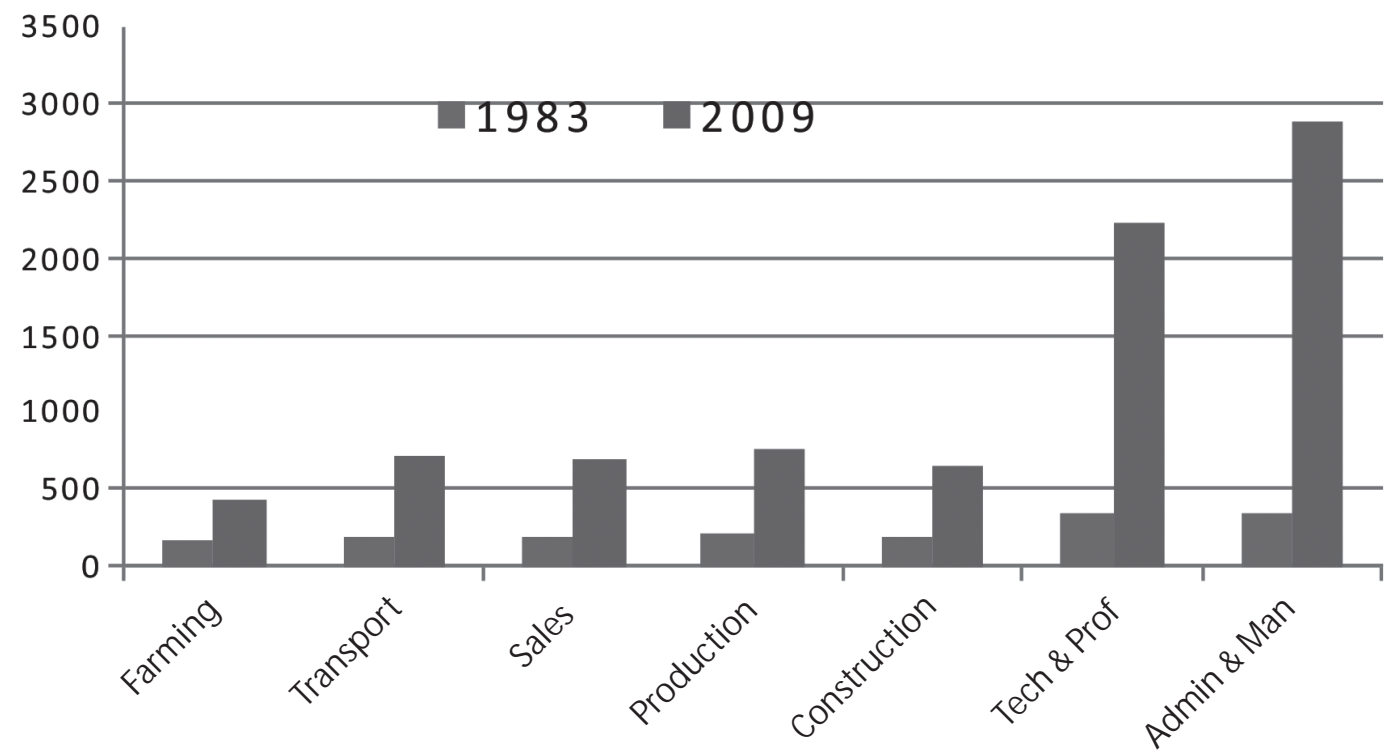

Source: Same as Table 14. 
Table 15: Growth in Real Wage by Occupation and Socio-religious Group

\begin{tabular}{lcccc}
\hline \multicolumn{1}{c}{ Sector / Occupation } & \multicolumn{4}{c}{ 1983-2009 (\% pa) } \\
\hline Farming & HST & HSC & HUC & MUS \\
Transport & 7.8 & 6.5 & 3.5 & 9.5 \\
Sales & 11.1 & 12.0 & 7.2 & 15.8 \\
Production & 10.5 & 10.2 & 10.9 & 9.3 \\
Construction & 10.5 & 7.2 & 12.3 & 10.0 \\
Tech \& Prof & 7.9 & 7.8 & 7.7 & 17.1 \\
Admin \& Man & 18.9 & 58.9 & 14.7 & 26.2 \\
\hline
\end{tabular}

Source: Author's calculation based on NSSO $(1983,2010)$.

The distress is all the more evident if we look at the gender dimension. It is observed that the rural female workers have witnessed very little changes over the years. Their dependence on agriculture is as high as 80 per cent even in 2009 and share of casual wage labour has been steady around 42- 44 per cent. It is the males who have been shifting out of land-based activities and for whom casualisation has increased by more than 10 percentage points. All these indicate that rural male agricultural workers and self-cultivators under duress are venturing into seasonal, casual off-farm jobs to supplement family income while the farm-jobs are entrusted to the women folk of the household. Bereft of adequate human capital, the surplus male labourers get into low-productive, low-paid manual jobs which have pathetic work conditions and unsure duration. The distressdriven employment growth in the rural nonfarm sector observed by researchers during the decade 1993-2004 has clearly extended its stay. The transformation process is, therefore, more cosmetic than meets the eye and indicates stagnation rather than mobility.

\section{Conclusion}

What are the clear messages coming out of this analytical exercise? First, evidence shows that the transformation process currently underway in the rural labour market in India is a stunted one. The fluidity that is being observed and manifesting itself as mobility of labour across sectors are more apparent than real. Second, even this mobility is limited to a small sub-section of the population. This section, predominantly the upper caste households, is having a dynamic change and moving out of low productive primary landbased occupations to better paying secondary and tertiary jobs. Third, for the majority population the movements are distress-driven and from one low paying job to another with frequent seasonal switches between them. Fourth, such a para-normal transformation process is caused to a large extent by low agricultural productivity, adverse man-land ratio and lack of capital formation in rural India which is pushing out surplus labour. Fifth, these workers lack the human capital (education and skill) demanded by modern secondary and tertiary sectors to get opportunities in the 
urban/peri-urban sectors. Sixth, constricted growth of labour-intensive small and medium non-farm enterprises in rural areas are also preventing these workers from gaining access to non-primary jobs that are regular and better-paying but located in rural areas.

Under such a situation, what may be the likely solution? In our opinion, the policy thrust has to be three-pronged. First, improving agricultural productivity through capital formation should be the top priority. Public capital formation in agriculture has been dwindling over the last two decades and the negative impact is felt by the small and marginal farmers (the largest segment in terms of population linked with them) as they lack private capital to tide over this shortfall. Stabilisation of costs and prices, should also lead to better returns from cultivation and farm related activities. While at present the input market has mostly been left to the market, asymmetry and bottlenecks in the product market hinder the farmers benefiting from marketing their products. Second, ensuring skill formation among rural youth will go a long way in developing the human capital base of rural India and enabling the rural youth take up nonfarm jobs and even become entrepreneurs. The Prime Minister Kaushal Vikas Yojana is a bold step in this regard and may change the rural dynamics in long-run. Third, supply of skilled manpower will not solve the problem unless there is a simultaneous proliferation of rural industries that have high employment elasticity.Thus, contrary to popular perception, the changes in rural labour dynamics do not call for policy holiday for agriculture sector though apparently its share in employment is declining. Rather this sector calls for immediate support to convert the rural transformation process from being distress-driven to growthoriented.Sadly, governments over the last two decades have relied more on agricultural subsidies rather than public investment to pay lip service to the rural economy. It is high time that policies take a bend in the river, otherwise rural economy will surely capsize, an eventuality that urbanising India cannot afford.

[This paper was presented at the Annual Conference of Indian Society of Labour Economics held at J awaharlal Nehru University, New Delhi in December,2013 and also at the Department of Economics, Calcutta University in February, 2014. The author has benefited from comments received during the two presentations and thanks the participants for the same. Thanks are also to anonymous referees for revisions that enriched the paper]

\section{Notes}

${ }^{1}$ The NSSO conducts periodical large sample surveys on employment, unemployment, consumption expenditure of the people, etc. These surveys provide information on employment status, broad occupation groups, wages earned by each individual and also the Monthly Percapita Consumption Expenditure for each family. For further details on NSSO Surveys, see www.mospi.nic.in.

Journal of Rural Development, Vol. 36, No. 1, January - March : 2017 


\section{References}

1 Abraham,V (2009),“Employment Growth in Rural India:Distress-Driven?”,Economic \& Political Weekly, Vol.44, No.16, April 18, 2009, pp.97-104.

2 Alagh,Yoginder K (2004), “State of the Indian Farmer: A Millennium Study”, Volume 1:An Overview, Academic Foundation and Government of India, New Delhi.

3 Bhalla, Sheila (2003), "India's Rural Economy:Issues and Evidence,"Institute for Human Development, mimeo.

4 Bhaumik, SK (2002), "Employment Diversification in Rural India: A State Level Analysis", The Indian Journal of Labour Economics, Vol. 45, No 4.

5 Binswanger-M khize, Hans P (2013), "The Stunted Structural Transformation of the Indian Economy: Agriculture, Manufacturing and the Rural Non-Farm Sector",Economic and Political Weekly, Vol. 48, No. 26-27, J une 29.

6 Chadha, G.K. and Sahu, P.P (2002), "Post-reform Setbacks in Rural Employment: Issues that Need Further Scrutiny,"Economic and Political Weekly, Vol. 37, No. 21, May 25, 2002, pp.1998-2026

7 Coppard, Daniel (2001), “The Rural Non-farm Economy in India: A Review of the Literature”, Natural Resource Institute, Department for International Development (DFID), World Bank, NRI Report No 2662, November.

8 Deshingkar, Priya and John Farrington (2006), "Rural Labour Markets and Migration in South Asia: Evidence from India and Bangladesh", Background Paper for the World Development Report 2008,

9 Eswaran,M.A.Kotwal,B.Ramaswami and W.Wadhwa (2009),"Sectoral Labour Flows and Agricultural Wages in India, 1983-2004: Has Growth Trickled Down?", Economic \& Political Weekly, Vol. 44, No. 2, January 10, 2009, pp. 46-55

10 Fisher, T. and V. Mahajan (1998), The Forgotten Sector: Non-farm Employment and Enterprises in Rural India",Intermediate Technology Publications, London.

11 ICSSR (2009),"'ICSSR J ournal of Abstracts and Reviews - Economics,'Indian Council of Social Science Research, New Delhi.

12 Jatav, Manoj and Sucharita Sen (2013), "Drivers of Non-Farm Employment in Rural India: Evidence from the 2009-10 NSSO Round",Economic and Political Weekly, Vol. 48, No. 26-27, J une 29.

13 Jha,Brajesh (2006), “Rural Non-Farm Employment in India:Macro-Trends, Micro-Evidences and Policy Options", IEG Working Paper Series No. E/272/2006, IEG, New Delhi. [available from iegindia.org/ workpap/wp267.pdfý, accessed on 12-10-2013].

14 NSSO (1983), "Unit Level Records on Second Quinquennial Survey on Employment and Unemployment in India 1983-84, NSS 38 ${ }^{\text {th }}$ Round - July 1983-June 1984", National Sample Survey Organisation: Government of India.

15 NSSO (2010), “Unit Level Records on Eighth Quinquennial Survey on Employment and Unemployment in India 2009-10, NSS 66 $6^{\text {th }}$ Round - July 2009-June 2010", National Sample Survey Organisation: Government of India.

16 Ranjan, Sharad (2009), "Rural Non-Farm Employment in India:A Review Based on Recent Evidence”, Journal of Rural Development, Vol. 28, No. 1, pp. 73 - 84

17 Sastry, N.S. (2002), “Work Opportunities for Indian Rural Labour Force: Recent Knowledge and Thinking", Journal of Indian Society of Agricultural Statistics, Vol. 55, No. 3, pp. $288-96$. 